\title{
Concentrations of testosterone and androsterone in peripheral and umbilical venous plasma of fetal rats
}

\author{
J. T. M. Vreeburg, J. O. Groeneveld, P. E. Post and M. P. Ooms \\ Department of Endocrinology, Growth and Reproduction, Faculty of Medicine, Erasmus University, \\ P.O. Box 1738, 3000 DR Rotterdam, The Netherlands
}

\begin{abstract}
Summary. Mean \pm s.d. testosterone concentrations in the peripheral plasma of 21 - and 22-day-old male fetuses $(1.32 \pm 0.43 \mathrm{ng} / \mathrm{ml})$ were significantly $(P<0.05)$ higher than those in the umbilical venous plasma $(0.37 \pm 0.08 \mathrm{ng} / \mathrm{ml})$. Testosterone concentrations in umbilical venous plasma of male and female $(0.29 \pm 0.06 \mathrm{ng} / \mathrm{ml})$ fetuses and in peripheral plasma of female fetuses $(0.36 \pm 0.10 \mathrm{ng} / \mathrm{ml})$ were not significantly different. Androsterone levels measured in umbilical venous plasma of male (11.5 \pm $2 \cdot 5 \mathrm{ng} / \mathrm{ml})$ and female $(12 \cdot 3 \pm 2 \cdot 1 \mathrm{ng} / \mathrm{ml})$ fetuses were nearly as high as those in peripheral plasma (males, $12.9 \pm 3 \cdot 1$; females, $13.3 \pm 3.5 \mathrm{ng} / \mathrm{ml}$ ). There were high concentrations of androsterone in the placentas of male $(33 \pm 4 \mathrm{ng} / \mathrm{g})$ and female $(33 \pm$ $5 \mathrm{ng} / \mathrm{ml}$ ) fetuses, suggesting that this organ is the major source of fetal androsterone. We also conclude that a major part of the testosterone present in female fetuses is secreted by the placentas.
\end{abstract}

\section{Introduction}

Plasma concentrations of testosterone are higher in male than in female rat fetuses (Turkelson, Dunlap, MacPhee \& Gerall, 1977; Slob, Ooms \& Vreeburg, 1978, 1980; Weisz \& Ward, 1980) although the values in female fetuses may occasionally exceed those of their male litter mates (Weisz \& Ward, 1980). There is evidence that the high prenatal testosterone concentrations in male fetuses are produced by the testes (Warren, Haltmeyer \& Eik-Nes, 1973; Picon \& Ktorza, 1976; Feldman \& Bloch, 1978), but the source of the testosterone in female fetuses is unclear. Since the ovaries are unlikely to secrete significant amounts of testosterone (Noumura, Weisz \& Lloyd, 1966; Warren et al., 1973; Slob et al., 1980) and the testosterone levels in female rats decrease rapidly after birth (Slob et al., 1980; Weisz \& Ward, 1980), the site of testosterone production is presumably outside the female fetuses, e.g. male littermates and the placentas. It has been suggested that in polytocous rodents, androgens might diffuse from male fetuses into the circulation of the female fetuses (Clemens, Gladue \& Coniglio, 1978; vom Saal \& Bronson, 1980; Meisel \& Ward, 1981).

During pregnancy, the maternal serum androgen levels are elevated (Gibori \& Sridaran, 1981; de Greef, Schenck, Vreeburg, van der Vaart \& Baum, 1981; Sridaran, Basuray \& Gibori, 1981). Removal of ovaries, adrenals and fetuses from pregnant rats did not affect the androgen levels in their peripheral serum but when the placentas were removed serum androgen dropped dramatically (Gibori \& Sridaran, 1981). The placenta therefore seems to secrete androgens into the maternal circulation (Sridaran et al., 1981). Whether this organ also provides androgens to the fetuses is unknown.

The present study was undertaken to investigate the placental secretion of testosterone and androsterone into the fetal circulation. Androsterone was measured because incubations of placental tissue with progesterone or androstenedione resulted in the formation of large amounts of androsterone (Townsend \& Ryan, 1970; Rembiesa, Marchut \& Warchol, 1972). 


\section{Materials and Methods}

\section{Animals}

Locally bred hooded $(\mathrm{R} \times \mathrm{U}) \mathrm{Fl}$ hybrid rats derived from two inbred Wistar rat strains were used. They were 3-6 months old, kept under controlled conditions of temperature $\left(20-24^{\circ} \mathrm{C}\right)$ and exposed to a reversed day-night cycle (lights off $08: 00-22: 00 \mathrm{~h}$ ). Pelleted food (Hope Farms Standard Laboratory Diet) and water were always available. At $3 \mathrm{~h}$ after the beginning of the dark period oestrous female rats were selected based upon their behaviour when a male rat was introduced into their home cage. The females were mated between $12: 00$ and $14: 00 \mathrm{~h}$. The day of mating was considered to be Day 1 . On Day 21 or 22 of pregnancy, rats were anaesthetized with urethane (Brocades-ACF, Maarssen, The Netherlands; $1.2 \mathrm{~g} / \mathrm{kg}$ body wt, administered i.p. as a $20 \%(\mathrm{w} / \mathrm{v})$ solution in $0.9 \%(\mathrm{w} / \mathrm{v}) \mathrm{NaCl})$. The fetuses were exposed, allowing the placenta and umbilical cord to remain in situ. Heparin (Thromboliquine: Organon, Oss, The Netherlands) 0.02 $\mathrm{ml}$ was injected s.c. into the fetus and $2 \mathrm{~min}$ later peripheral or umbilical venous blood was collected. A small incision in the umbilical vein was made with iridectomy scissors and a glass capillary was inserted into the vein. After collecting umbilical venous blood for about $10 \mathrm{~min}$ the fetus and its placenta were removed from the uterus. Subsequently, the jugular and carotid vessels of another fetus were cut and peripheral blood was collected in glass capillary tubes. In this way the collection of umbilical venous blood was alternated with that of peripheral blood. The sex of the fetuses was determined by identifying the gonads macroscopically under a dissecting microscope. Blood from fetuses of the same sex was pooled. Since the amount of plasma obtained from one fetus was small $(0.05-0 \cdot 10 \mathrm{ml})$, blood from fetuses of 2 litters was pooled. The number of fetuses contributing to a single pool varied between 4 and 8 . To obtain placental tissue 5 pregnant rats were anaesthetized with urethane on Day 21 of pregnancy. Placentas from male and female fetuses belonging to one litter were pooled and kept frozen at $-20^{\circ} \mathrm{C}$.

\section{Hormone determinations}

Testosterone and androsterone were purchased from Steraloids Inc. (Wilton, New Hampshire, U.S.A.). $\left[1,2,6,7-{ }^{3} \mathrm{H}\right]$ Testosterone (sp. act. $100 \mathrm{Ci} / \mathrm{mmol}$ ) was purchased from The Radiochemical Centre, Amersham, U.K. ; $\left[1,2-{ }^{3} \mathrm{H}\right]$ androsterone (sp. act. $41 \mathrm{Ci} / \mathrm{mmol}$ ) was purchased from New England Nuclear Corporation, Boston, U.S.A.

Testosterone concentrations were estimated by radioimmunoassay (RIA), using the method first described by Verjans, Cooke, de Jong, de Jong \& van der Molen (1973). A chromatography step was not carried out because Slob et al. (1978) found no differences in the concentrations of testosterone measured with and without chromatography on alumina micro-columns. From each plasma sample 75 and $150 \mu \mathrm{l}$ were used in the assay. The sensitivity of the assay was $<10 \mathrm{pg}$ per tube. The interassay and intra-assay coefficients of variation were $15 \%$ and $7 \%$ respectively.

Plasma androsterone concentrations were measured by RIA (Zamecnik, Barbe, Moger \& Armstrong, 1977; de Greef et al., 1981) using the OA-1 antiserum supplied by Dr D. T. Armstrong (London, Ontario, Canada). This antiserum is highly specific for androsterone; from a variety of 21 steroids only $5 \alpha$-androstane- $3 \alpha, 17 \beta$-diol had appreciable cross-reactivity $(27 \%)$. The crossreactivity of the other steroids was $<0.4 \%$. Therefore, in most samples androsterone was measured without chromatography. In a few samples, however, androsterone was estimated with and without thin-layer chromatography on a glass plate coated with alumina $(0.25 \mathrm{~mm})$. The solvent system used to develop the plate was toluene : acetone $(85: 15, \mathrm{v} / \mathrm{v})$. The areas of androsterone were scraped off and eluted twice with $1.5 \mathrm{ml}$ ether : hexane $(50: 50, \mathrm{v} / \mathrm{v})$. To measure placental androsterone, the tissue was homogenized in distilled water $(1: 10, \mathrm{w} / \mathrm{v})$ at $0^{\circ} \mathrm{C}$ with a stainless-steel homogenizer (Ultra Turrax, Janke and Kunkel K.G., Staufen, West Germany). The procedure for measuring androsterone in placental homogenates was similar to that described for plasma. In 2 homogenates androsterone was measured with and without chromatography. The androsterone concentrations 
in plasma were determined in 10 and $20 \mu \mathrm{l}$, those in tissue in 75 and $150 \mu$ lof the homogenate. The sensitivity of the assay was $<20 \mathrm{pg}$ per tube. The interassay and intra-assay coefficients of variation for the androsterone determination were $14 \%$ and $9 \%$ respectively.

\section{Statistical analysis of data}

Results expressed as mean \pm s.d. were analysed by Student's $t$ test, and were considered to be significant if $P<0.05$.

\section{Results}

In 21-day-old fetuses (Text-fig. 1a), the testosterone concentration $(1.32 \pm 0.43 \mathrm{ng} / \mathrm{ml})$ in peripheral plasma of male fetuses was significantly higher $(P<0.01)$ than that in umbilical vein plasma of males $(0.37 \pm 0.08 \mathrm{ng} / \mathrm{ml})$ and females $(0.27 \pm 0.06 \mathrm{ng} / \mathrm{ml})$ and peripheral plasma of females $(0.36 \pm 0.10 \mathrm{ng} / \mathrm{ml})$. There were no significant differences between these last 3 values for testosterone concentrations.

Half of the plasma pools used for androsterone measurements had already been used for testosterone estimations. As shown in Text-fig. 1(b) the mean androsterone concentrations in the peripheral plasma of male $(12.9 \pm 3.1 \mathrm{ng} / \mathrm{ml})$ and female fetuses $(13.3 \pm 3.5 \mathrm{ng} / \mathrm{ml})$ were as high as those in the umbilical vein of male $(11.5 \pm 2.5 \mathrm{ng} / \mathrm{ml})$ and female $(12 \cdot 3 \pm 2 \cdot 1 \mathrm{ng} / \mathrm{ml})$ fetuses.
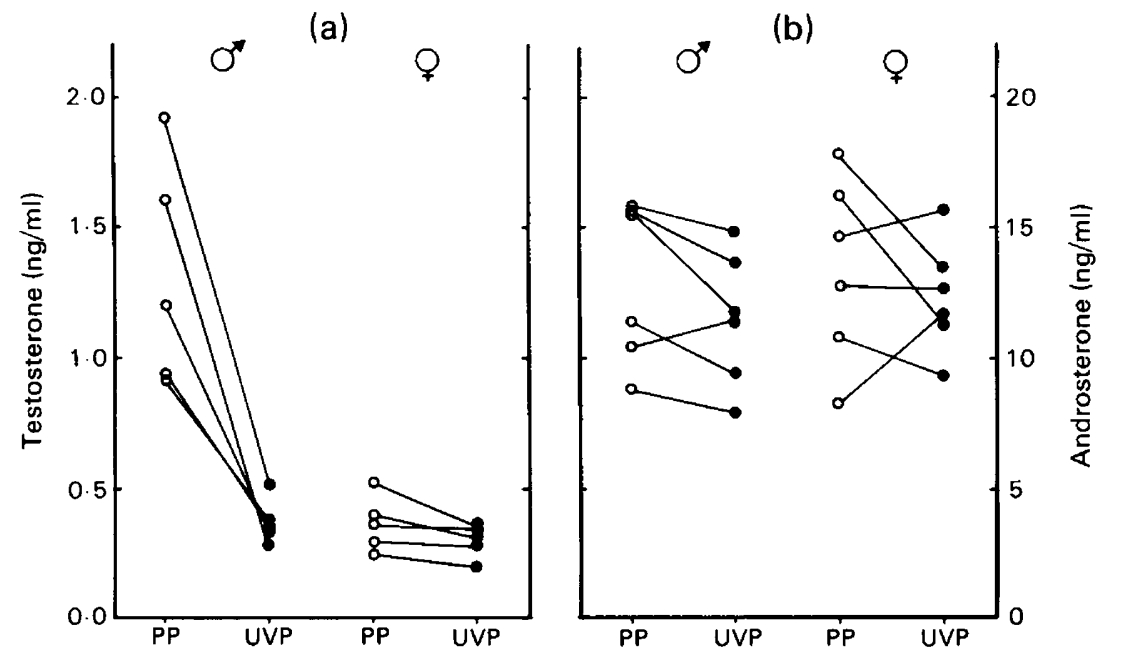

Text-fig. 1. Testosterone (a) and androsterone (b) concentrations in peripheral $(P P, O)$ and ùmbilical (UVP, ) venous plasma of male and female rat fetuses. Values determined in umbilical and peripheral venous plasma samples obtained from the same litters are connected by a solid line.

The concentrations of androsterone measured in placental tissue were even higher than those found in fetal plasma, and for male and female fetuses the values were $33 \pm 5$ and $33 \pm 4 \mathrm{ng} / \mathrm{g}$ tissue, respectively. The androsterone values for 5 pools of fetal plasma and 2 pools of placental tissue measured with alumina thin-layer chromatography were approximately $24 \%$ lower than those estimated without chromatography. 


\section{Discussion}

The results of the present study demonstrate a clear-cut sex difference in the peripheral plasma testosterone levels of 21-day-old fetuses. The testosterone concentrations in peripheral plasma of 21-day-old male fetuses were higher than those measured previously by Slob et al. (1980) but equivalent to those reported by Weisz \& Ward (1980).

The lower testosterone concentrations in umbilical vein blood of male fetuses than in peripheral plasma show that a major part of the testosterone disappears from male fetal blood during circulation through the placenta. This might explain why plasma testosterone levels rise markedly in newborn rats during the first few hours after birth (Corbier, Kerdelhue, Picon \& Roffi, 1978; Slob et al., 1980). At birth the connection between fetus and placenta is broken so that the placental clearance of testosterone stops and the plasma concentration of this androgen rises. In contrast to the males, in female fetuses the testosterone concentrations in umbilical vein blood were almost as high as those measured in peripheral plasma. In female fetuses therefore testosterone is not cleared from blood that circulates through the placenta. These seemingly contradictory data could be reconciled if one assumes that the placenta itself contains testosterone. Indeed, it has been shown that the placenta possesses the enzymes to convert pregnenolone and progesterone into testosterone (Chan \& Leathem, 1975). Therefore, during circulation of fetal blood through the placenta, testosterone will exchange between fetal blood and placental tissue, so that the concentration of unbound testosterone in fetal umbilical vein blood will approach that in placental tissue. Since in female fetuses the gonads do not secrete testosterone, the testosterone levels in the peripheral plasma of female fetuses are similar to those found in umbilical vein blood.

The peripheral levels of androsterone were as high in male as in female fetuses. Since high levels of androsterone were present both in the placenta and in the umbilical vein plasma the placenta is probably the source of this $5 \alpha$-reduced androstane compound in fetal plasma. This suggestion is supported by the fact that the progesterone concentration in the placenta is high (Csapo \& Wiest, $1969)$ and that in this organ in vitro an active conversion of progesterone to androsterone occurs (Rembiesa et al., 1972). It is not known whether androsterone is formed exclusively from testosterone and androstenedione or also from $5 \alpha$-reduced pregnane compounds. The latter steroids are present in large amounts after incubations of placental tissue with pregnenolone or progesterone (Townsend \& Ryan, 1970; Rembiesa et al., 1972; Chan \& Leathem, 1975).

Appreciable amounts of androgens occur in the peripheral plasma of pregnant rats (Gibori \& Sridaran, 1981; de Greef et al., 1981). Our data confirm the suggestion that the placenta might be a major site for the production of these androgens (Gibori \& Sridaran, 1981; de Greef et al., 1981; Sridaran et al., 1981). The unexpectedly high levels of androsterone found in fetal (present study) and maternal plasma (de Greef et al., 1981), and the extensive placental steroid metabolism, raises the question whether and in which amounts other $5 \alpha$-reduced steroid compounds are present in fetal and maternal blood. This could be important since almost all testosterone-binding antisera have some cross reactivity with other steroids. Despite chromatography Weisz \& Ward (1980) obtained large differences in concentrations of fetal plasma testosterone measured using four different antisera.

We thank Dr D. T. Armstrong for the generous gift of the antiserum used in the androsterone assay; Dr J. J. van der Werff ten Bosch for reading the manuscript; and A. Bot and P. Woutersen for their assistance.

\section{References}

Chan, S.W.C. \& Leathem, J.H. (1975) Placental steroidogenesis in the rat: progesterone production by tissue of the basal zone. Endocrinology 96, 298303.
Clemens, L.G., Gladue, B.A. \& Coniglio, L.P. (1978) Prenatal endogenous androgenic influences on masculine sexual behavior and genital morphology in male and female rats. Horm. \& Behav. 10, 40-53. 
Corbier, P., Kerdelhue, B., Picon, R. \& Roffi, J. (1978) Changes in testicular weight and serum gonadotropin and testosterone levels before, during, and after birth in the perinatal rat. Endocrinology 103, 1985-1991.

Csapo, A.I. \& Wiest, W.G. (1969) An examination of the quantitative relationship between progesterone and the maintenance of pregnancy. Endocrinology 85, $735-746$.

de Greef, W.J., Schenck, P.E., Vreeburg, J.T.M., van der Vaart, P.D.M. \& Baum, M.J. (1981) Evidence that a placental factor other than androsterone or dihydrotestosterone inhibits oestrogen-induced lordosis behaviour in pregnant rats. $J$. Endocr. 89, 13-23.

Feldman, S.C. \& Bloch, E. (1978) Developmental pattern of testosterone synthesis by fetal rat testes in response to luteinizing hormone. Endocrinology 102, 999-1007.

Gibori, G. \& Sridaran, R. (1981) Sites of androgen and estradiol production in the second half of pregnancy in the rat. Biol. Reprod. 24, 249-256.

Meisel, R.L. \& Ward, I.L. (1981) Fetal female rats are masculinized by male littermates located caudally in the uterus. Science, N.Y. 213, 239-242.

Noumura, T., Weisz, J. \& Lloyd, C.W. (1966) In-vitro conversion of $7-{ }^{3} \mathrm{H}$-progesterone to androgens by the rat testis during the second half of fetal life. Endocrinology 78, 245-253.

Picon, R. \& Ktorza, A. (1976) Effect of LH on testosterone production by foetal rat testes in vitro. FEBS Letters 68, 19-22.

Rembiesa, R., Marchut, M. \& Warchol, A. (1972) Ovarian-placental dependency in rat. Part 1. Biotransformation of $\mathrm{C}_{21}$ steroids to androgens by rat placenta in vitro. Steroids 19, 65-84.

Slob, A.K., Ooms, M.P. \& Vreeburg, J.T.M. (1978) Sex ratio in utero and the plasma concentration of testosterone in male and female rat foetuses. $J$. Endocr. 79, 395-396.
Slob, A.K., Ooms, M.P. \& Vreeburg, J.T.M. (1980) Prenatal and early postnatal sex differences in plasma and gonadal testosterone and plasma luteinizing hormone in female and male rats. J. Endocr. 87, 81-87.

Sridaran, R., Basuray, R. \& Gibori, G. (1981) Source and regulation of testosterone secretion in pregnant and pseudopregnant rats. Endocrinology 108, 855-861.

Townsend, L. \& Ryan, K.J. (1970) In-vitro metabolism of pregnenolone- $-{ }^{3} \mathrm{H}$, progesterone-4- ${ }^{14} \mathrm{C}$ and androstenedione- $4{ }^{14} \mathrm{C}$ by rat placental tissue. Endocrinology 87, 151-155.

Turkelson, C.M., Dunlap, J.L., MacPhee, A.A. \& Gerall, A.A. (1977) Assay of perinatal testosterone and influence of antiprogesterone and theophylline on induction of sterility. Life Sci. 21, 1149-1158.

Verjans, H.L., Cooke, B.A., de Jong, F.H., de Jong, C.M.M. \& van der Molen, H.J. (1973) Evaluation of a radioimmunoassay for testosterone estimation. $J$. Steroid Biochem. 4, 665-676.

vom Saal, F.S. \& Bronson, F.H. (1980) Sexual characteristics of adult female mice are correlated with their blood testosterone levels during prenatal development. Science, N.Y. 208, 597-599.

Warren, D.W., Haltmeyer, G.C. \& Eik-Nes, K.B. (1973) Testosterone in the fetal rat testis. Biol. Reprod. 8, 560-565.

Weisz, J. \& Ward, I.L. (1980) Plasma testosterone and progesterone titers of pregnant rats, their male and female fetuses, and neonatal offspring. Endocrinology 106, 306-316.

Zamecnik, J., Barbe, G., Moger, W.H. \& Armstrong, D.T. (1977) Radioimmunoassays for androsterone, $5 \alpha$-androstane- $3 \alpha, 17 \beta$-diol and $5 \alpha$-androstane-

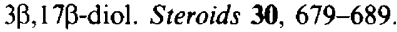

Received 9 September 1982 